\title{
Integrated Grid-connected Hybrid Power Generating System with Optimized PLL-based Power Control
}

\author{
Pawan PANDEY ${ }^{1, *}$ and Kanwarjit SANDHU ${ }^{2}$ \\ ${ }^{I}$ Department of Electrical Engineering, Jabalpur Engineering College, Jabalpur, India \\ ${ }^{2}$ Department of Electrical Engineering, National Institute of Technology, Kurukshetra, India
}

('Corresponding author's e-mail: pkpnitj@gmail.com)

Received: 23 March 2021, Revised: 8 May 2021, Accepted: 15 May 2021

\begin{abstract}
In this paper, grid-connected photovoltaic-wind energy, including a battery energy storage system (BESS) with a novel topology base proposed controller, is presented. The battery can be reflected in a smooth and stable output under variation of weather and load conditions for the grid-connected system. Robust phase-locked loop- (PLL) based hybrid Voltage Source Converter (VSC) controller is designed to enhance power quality (PQ) with mitigating power fluctuation at DC-link by applied BESS on the DC side. The results can be summarized in 2 stages; in the $1^{\text {st }}$ stage, the performance of the designed hybrid system can be analyzed with untuned parameters of the converter, and in the $2^{\text {nd }}$ stage, a simple strategy base proposed controller to improve the operation stability and analyze the PQ of the hybrid power generating (HPG) system is developed. Finally, the proposed hybrid system is modeled in MATLAB/Simulink and the simulation results as obtained are compared with an existing controller.
\end{abstract}

Keywords: Hybrid power generating system, Renewable energy, Energy storage system, Power quality, VSC controller

\section{Introduction}

At present, due to the increasing application of electrical energy in various sectors, the continuous demand for electrical energy has increased. This is represented in the outbreak of pollution, as a major amount of generated electricity is generated using fossil fuel. Fossil fuel will be exhausted after a few years, and so, renewable energy sources are the only alternative to compensate for future energy demand. To resolve this problem, photovoltaic (PV) and wind hybrid power generation systems are growing rapidly as renewable energy sources. However, weather condition is a weakness of photovoltaic and wind systems. Therefore, PV and wind generating system output can be stable and reliable with the aid of battery energy storage (BES), which can enhance the effective performance of the entire grid-connected generation system mode.

A grid-connected PV/wind power generating system has been emphasized reforming DC-link voltage fluctuations and suitable resizing of the DC-link capacitor bank [1]. A photovoltaic system, a wind turbine, energy storage, and an AC load is a brief description of the hybrid system that has been presented, and where a power converter is connected to each DC-link [2]. Remedial measures for power fluctuations through energy storage have also been investigated in some studies [3-8]. Most of the research indicates overcoming fluctuations in the output power of the hybrid system controlled by the state of charge (SOC) of the battery [8]. Some studies have attempted new methods for the study and conditioning of hybrid structures using battery systems [5,6]. Additionally, several studies have attempted new control schemes in hybrid systems [9-12]. Wind energy plays an important role to compensate for the demand of the electrical energy here and has been presented as a continuous-power control scheme of a 
http://wjst.wu.ac.th

novel 2-stage for a wind farm armed with a double fed induction generator (DFIG), where the DFIG and supercapacitor energy storage system connected with a DC-link; this has been discussed with the same structural system [10] but characterized by virtual inertia to enhance system stability and dynamic behavior, as presented in [11]. A new energy management strategy is presented for the hybrid DFIG/SC/BESS system. In this paper, the integrated operation of BESS and supercapacitor (SC) is carried out through the execution of an energy management algorithm and permits the authors to remove the voltage loop of the battery [13,14]. From the last few decades, Introduces a power management and new control of a hybrid system containing a wind, PV system, and a battery bank [12]. The battery bank takes advantage of having only 1 current control loop in its control structure. Another embedded energy share method between high battery energy storage systems and auxiliary energy storage systems has been introduced in [15].

Almost all expectations and opportunities for integrating PV and wind electric power generating sources for both grid-connected and stand-alone methods are discussed in a comprehensive review [16, 17], while full dynamic modeling, design, and design of a grid control strategy-connected PV/wind hybrid power systems without energy storage installation are investigated in [18]. In [19], the authors propose to create a hybrid energy storage system for high-level superconductor SMES with commercially available battery systems to mitigate potential issues due to a massively distributed distribution, such as voltage surge, flow, and voltage imbalance in reverse power distribution systems. The behavior of the battery/SMES hybrid energy storage system used in fuel cell/renewable energy hybrid power systems under unpredictable load profile and variable RES power is studied in [20]. As different sources of renewable energy along with different systems available for storing energy collectively leads to the formation of a hybrid renewable energy system, only by the application of appropriate control strategy can 1 obtain reliable output at peak efficiency [21]. Thus, the controller has a major role to play in this hybrid renewable energy system, as it is required for monitoring and load. It also keeps proper tracking of the output voltage and frequency, as well as different energy sources for determining the active and reactive power. So, for a hybrid renewable energy system, the choice of the controller must be wisely made, as per the requirements of different energy sources, output power, and control strategies.

Some improvements in the quality of a power generating system can be seen by mere battery connection but charging and discharging control of battery is a challenging task for a system under conditional operator. We would like to operate in the maximum power point tracking MPPT zone, the region of the set of the operating point, which is nearest MPPT now, the lower voltage point $V_{\min }$ and higher voltage point as defining $V_{\max }$ now if the battery voltage range is within $V_{\min }$ and $V_{\max }$ than the hybrid system, battery, and load are connected. If the battery voltage is less than $V_{\min }$, then the battery is not in charge condition and, therefore, the battery has to be disconnected from the load. It will be directly connected to the hybrid system, so it will be charging with almost the full system current and another region above $V_{\max }$. We will connect the battery to the load and disconnect from the hybrid system which has been performed by the proposed battery control with bidirectional DC/DC converter and, with it on the other side, a suitable controller proposed that controls fluctuations and poor PQ in grid-connected $\mathrm{PV} /$ wind/battery power generating systems under environmental and load variations.

In this paper, the proposed controller is designed for inverter and BESS with PV/Wind hybrid generating system connected to the grid under different operating conditions. All issues related to PQ, such as voltage sag, swell, interruption, total harmonics distortion (THD), active power, reactive power, etc., have been integrated. The energy management system (EMS) is designed to manage each power converter in a coordinated manner, such that the performance of the hybrid system is stable and enhances the PQ. On other side, a BESS with the bidirectional current controller interlink with the hybrid control scheme has been added to a PV/Wind system managed by EMS. The battery plays a vital role to compensate the fluctuation on the DC side and fills the gap between the power generation and consumption. The proposed system has been performed in 2 situations. First, the input pulse of the inverter is replaced by a simple 3-level pulse width modulation (PWM) generator, instead of the proposed controller, and all aspects of the system have been examined. The PLL-based controller has been proposed for the inverter, which smooths the DC-link voltage fluctuation and permits the maximum power to the grid system with help of a reference current (MPPT current). 


\section{Modeling of the system components/Methodology and experimentation}

Figure 1 shows the proposed HPG system configuration. The grid-connected PV/Wind/Battery system is connected to the common DC bus and AC bus. The power electronics DC/DC converter is interfacing between the HPG system to the DC bus and the AC/DC converter is interconnected to the AC and DC bus.

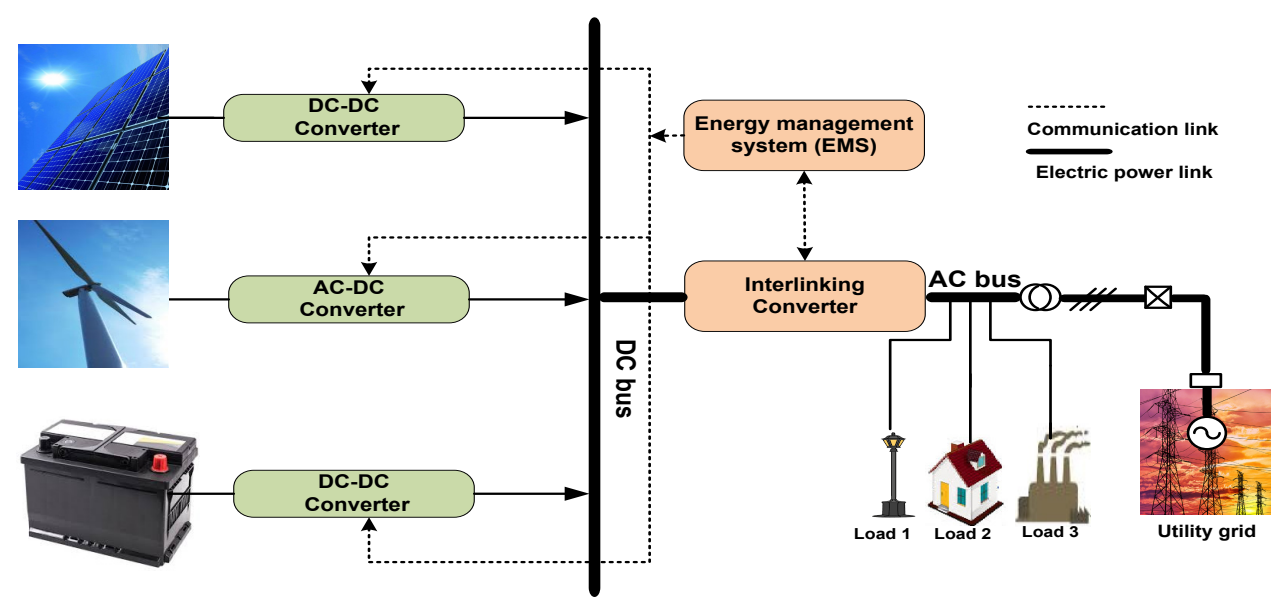

Figure 1 Equivalent model of the grid-connected hybrid systems.

There are 3 loads connected through switches at the AC bus line of the system. The maximum power can be achieved by both DC/AC converters and the proposed inverter controller in such a way that the power fluctuation is at DC-link under environment and load variation. During faulty and load variation, the PQ can be achieved by the proposed VSC, which maintains the unity power factor and feeds the maximum power to the grid.

\section{PV panels}

A PV system consists of a set of PV cells connected in series and parallel combinations. The characteristic of a PV system is characterized by a single PV cell, as shown in Figure 2, representing an equivalent model of the PV system and single PV cell configuration; the PV system can transform solar irradiation into electrical energy. The equivalent model of $\mathrm{PV}$ system $I_{P V}$ and $V_{P V}$ is the maximum generated current and voltage of PV array, where $V_{d c}$ is a DC-link voltage. According to Figure 2, each PV cell has behaved like a current source $\left(I_{p h}\right)$ which is generated by a light source. In a set of PV cells to produce the desired output power, the reverse saturation current $\left(I_{s}\right)$ is present in a parallel ideal diode, a shunt resistance $R_{p}$, and a series resistance $R_{s}$; using Kirchhoff's law determines the V-I, as follows [22]:

$$
I=I_{p h}-I_{o}\left[\exp \left(\frac{V+I R s}{A V_{t}}\right)-1\right]-\left[\frac{V+I R s}{R p}\right]
$$

Whereas the case of multi diode model of the PV cell may be expressed as:

$$
I=I_{p h}-\sum_{i=1}^{3} I_{o i}\left[\exp \left(\frac{V+I R s}{A_{i} V_{t}}\right)-1\right]-\left[\frac{V+I R s}{R p}\right]
$$


http://wjst.wu.ac.th

Where $I_{p h}=$ current generated by the incident light, $I_{o i}=$ Shockley $\mathrm{i}^{\text {th }}$ diode current, $I_{o i}=$ reverse saturation current of $\mathrm{i}^{\text {th }}$ diode, $q=$ electron charge, $1.6 \times 10^{-19} \mathrm{C}, \mathrm{A}_{\mathrm{i}}=$ ideality factor of $\mathrm{i}^{\text {th }}$ diode, and $V_{t}=k T / q$ is the thermal voltage, in which $k=1.38 \times 10^{-23} \mathrm{~J} / \mathrm{K}$, is the Boltzmann's constant, $T=\mathrm{p}-\mathrm{n}$ junction temperature in Kelvin. Dependence of the Photocurrent $\left(I_{p h}\right)$ on environmental parameters, i.e., temperature and irradiance, may be expressed as:

$$
I_{p h}=\left[I_{p h, n}+K_{i}\left(T-T_{r e f}\right)\right] \frac{S}{S_{n}}
$$

Dependence of diode saturation current is defined as:

$$
\begin{aligned}
& I_{0}=I_{0, n}\left(\frac{T}{T_{r e f}}\right)^{3} \exp \left[\frac{q E_{g}}{A K}\left(\frac{1}{T_{r e f}}-\frac{1}{T}\right)\right] \\
& I_{0, n}=\frac{I_{s c, n}}{\exp \left(\frac{V_{o c, n}}{A V_{t, n}}\right)-1} \\
& I=N p I_{p h}-N p \sum_{i=1}^{3} I_{o i}\left[\exp \left(\frac{V / N s}{A_{i} V_{t}}\right)-1\right]
\end{aligned}
$$

Where $I_{, n}=$ photocurrent at standard test conditions, $K_{i}=$ temperature coefficient of short circuit current, $T_{\text {ref }}=$ reference temperature, $S_{n}=$ irradiance at standard test condition, $I_{o, n}=$ saturation current at reference temperature, $I_{s c, n}=$ short circuit current at reference temperature, and $V_{o c, n}=$ open circuit current at reference temp. The standard test conditions happen with Irradiance as $1000 \mathrm{~W} / \mathrm{m}^{2}$, cell temperature as $25{ }^{\circ} \mathrm{C}$ and spectral distribution (Air Mass) Ai as 0.96. For ideal solar plate series resistance, $R_{s}$ will be $0.21 \Omega$ and the parallel resistance $R_{s h}$ will be infinite. Therefore, for the maximum power from the solar PV cell, $R_{s}$ will be negligible value and the $\mathrm{R}_{\mathrm{sh}}$ must have a higher value [23]. For the model comprising of numbers of the series cell, $\mathrm{N}_{\mathrm{s}}$, and parallel cell $N_{p}$, Eq. (6) may be used to define the current behavior.

In this paper, 'SunPower SPR-305E-WHT-D' PV modules are used for the hybrid system. The model parameters are given in Table 1. Figure 3 shows that when the solar input (irradiation) value increases, then the short circuit current of PV also increases, while increasing the other input solar cells temperature value would decrease the open-circuit voltage of the PV. As shown, the V-I \& P-I curves at different irradiation and cell temperature. The generated output power increases with increasing solar irradiation and decreases with increasing cell temperature. 


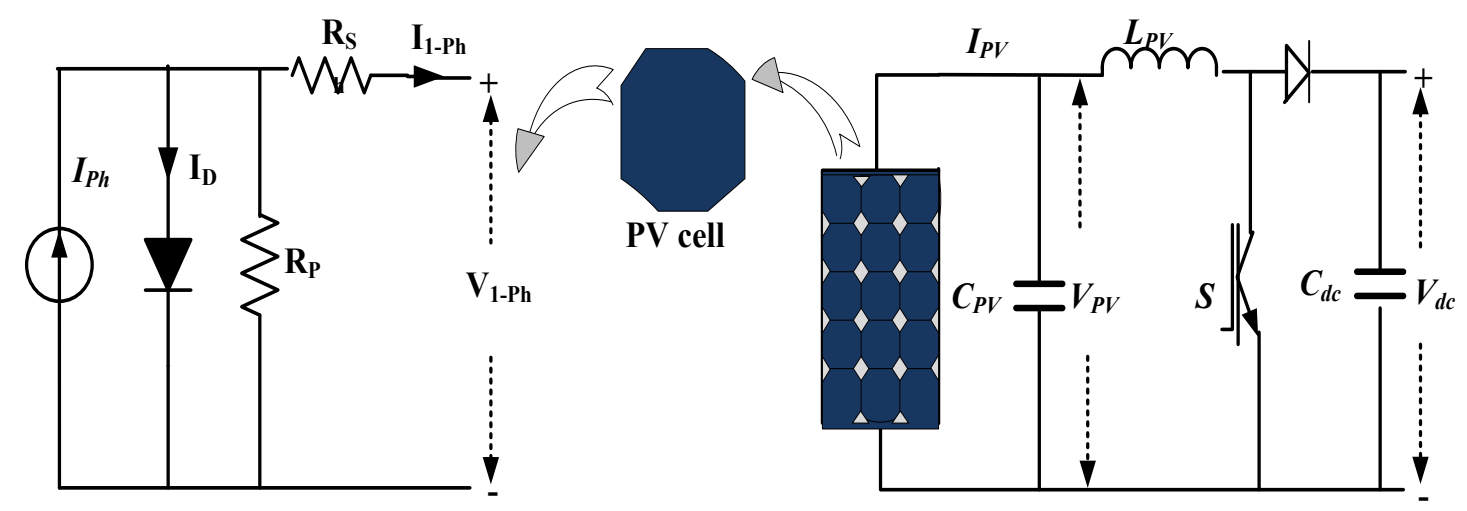

Figure 2 Equivalent model of single-diode PV cell and PV system configuration.
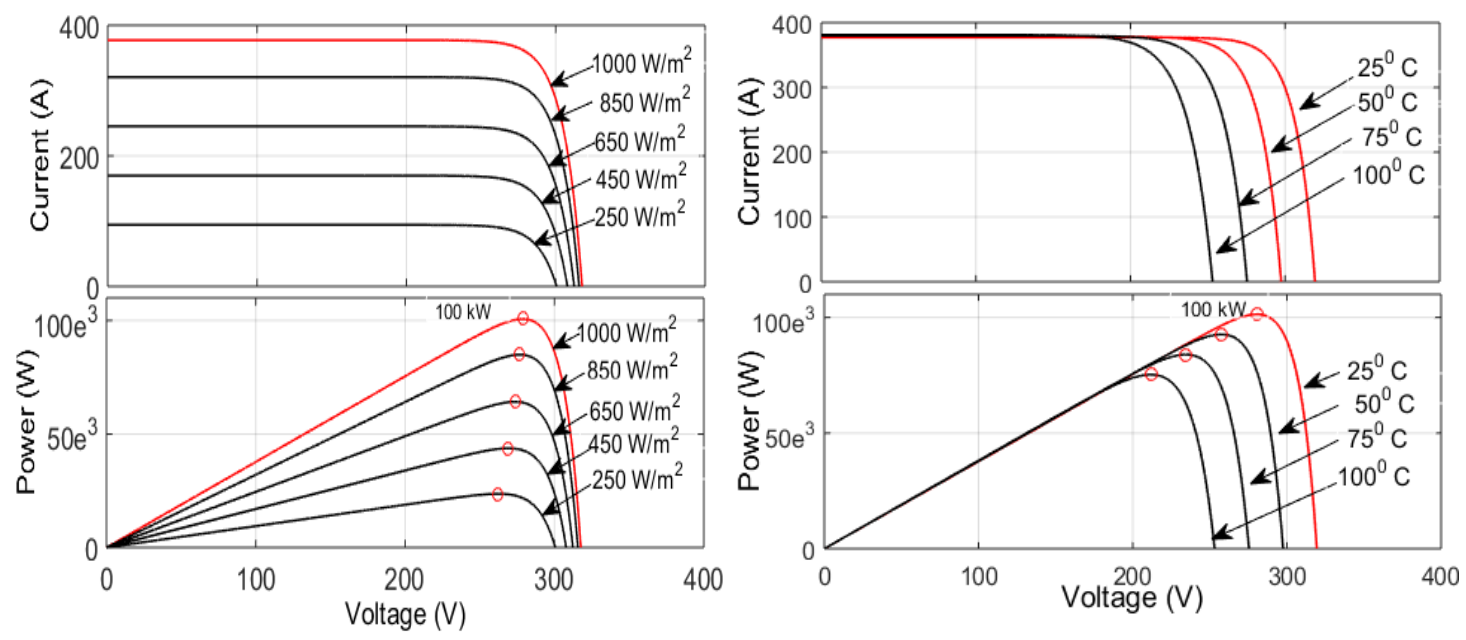

Figure 3 V-I and P-V curves at different solar irradiation levels and different cell temperature levels.

\section{Wind turbine}

The wind energy conversion process, along with actual mathematical modeling, includes wind turbine dynamics as well as generator modeling. Three blades have been installed, with horizontal axes and repair-free wind generators for modeling, as per the wind power structure system shown in Figure 4 [24]. The power output through a wind turbine can be calculated by the wind energy equation. The characteristic of the turbine is non-dimensional as speeds up the quantitative relation as a function of the tip. The output power and torque by the wind turbine have been estimated by the given formula[25]:

$$
P_{W T}=\left\{\begin{array}{cl}
0 & v_{w}<V_{c i} \text { or } v_{w}>V_{c o} \\
P_{W T_{r}} \frac{v_{w}-V_{c i}}{v_{r}-V_{c i}} & V c i<v_{w}<V_{c r} \\
P_{W T_{r}} & V c r<v_{w}<V_{c o}
\end{array}\right.
$$

Wind turbine developed torque is given as: 
$T_{T}=\frac{P_{W T}}{\omega}$

$\lambda=\frac{\omega R}{v_{w}}$

Where $T_{T}=$ the torque developed by the wind turbine, $P_{\mathrm{WT}}=$ output power; $P w t_{r}=$ the rated power output of the wind turbine, $V_{w}=$ the wind velocity in $\mathrm{m} / \mathrm{s}^{2}, V_{r}=$ the rated wind speed, $V_{c i}$ and $V_{c o}$ are the cut-in and cut-off speeds for the wind turbine, $C_{P}=$ the power co-efficient, $\lambda=$ the tip speed ratio, $\rho=$ the air density in $\mathrm{kg} / \mathrm{mg}^{3}$, and $A=$ the frontal area of a wind turbine [26].

Here, to find out the maximum power from wind energy, a control scheme devoid of an anemometer (wind speed sensor) was implemented. The generator torque is obtained with the help of the optimal torque-speed curve, as per the reference speed of the rotor. Then, by considering inertia, pole pairs, and magnetic flux linkage, the q component of the stator current will be calculated. Afterward, through PI control, the voltage reference for the stator will be obtained, which is the required converter voltage. The difference between the torque of the turbine and the torque of the generator determines the acceleration or deceleration of the generator. The turbine torque is larger than the generator torque; if the generator speed is less than the optimal speed, then the generator will be accelerated. Otherwise, if the generator speed exceeds the optimal speed, the generator will decelerate. Therefore, the turbine and generator torques settle at the optimal torque point at any wind speed, and the wind turbine is operated at the maximum power point [27].

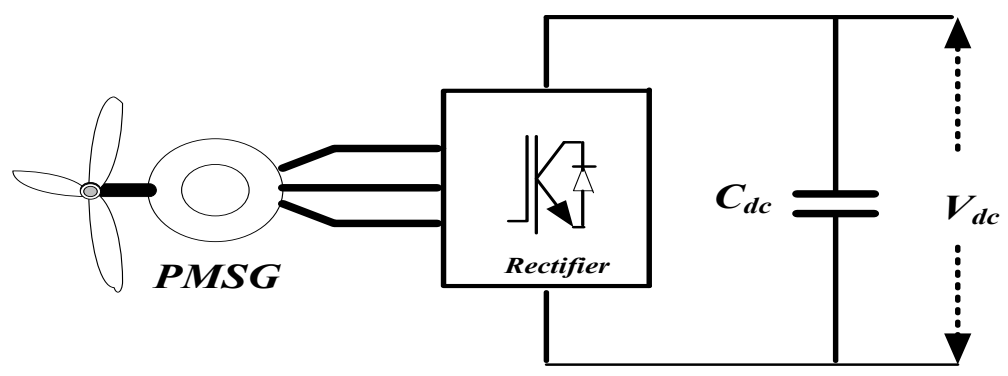

Figure 4 Wind power system structure.

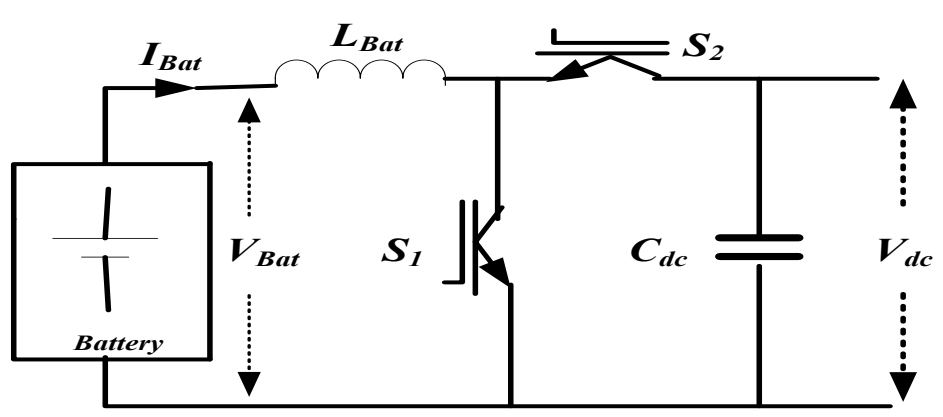

Figure 5 Battery energy storage system. 


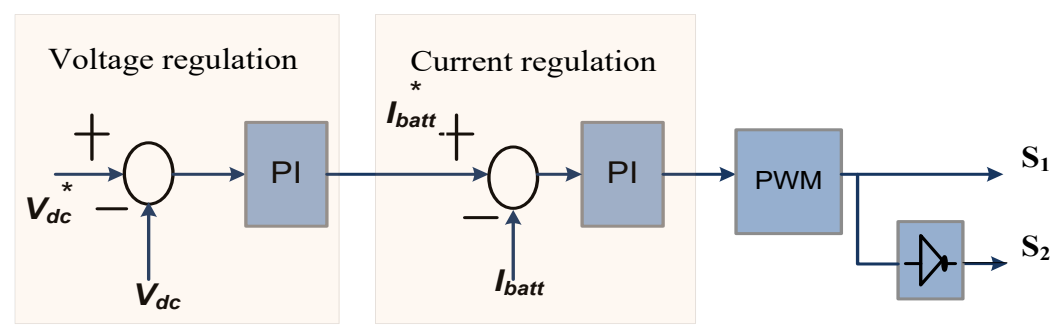

Figure 6 Battery controller.

\section{Battery modelling and control}

Where the intermissive nature of renewable energy resources and the fluctuating load demand are depicted in the energy storage system (ESS) structure, Figure 5, ESS is important to smooth the gap between the generation and depletion. ESS has 2 important parameters; the $1^{\text {st }}$ is terminal voltage, and the $2^{\text {nd }}$ is the state of charge (SOC) of the battery, presented as [27]:

$$
\begin{aligned}
& V_{\text {batt }}=V_{0}+R_{\text {batt }} I_{\text {batt }}-\frac{K Q_{\text {batt }}}{Q_{\text {batt }}+\int I_{\text {batt }} d t}+A_{\text {batt }} \exp \left(B_{\text {att }} \int I_{\text {batt }} d t\right) \\
& S O C=100\left(1+\frac{\int I_{\text {batt }} d t}{Q_{\text {batt }}}\right)
\end{aligned}
$$

Where $V_{\text {batt }}=$ terminal voltage of the battery, $V_{0}=$ the open-circuit voltage of the battery, $R_{\text {batt }}=$ internal resistance of the battery, $I_{\text {batt }}=$ charging current of the battery, $\mathrm{K}=$ polarization voltage, $Q_{\text {batt }}=$ battery capacity, $A_{\text {batt }}=$ the exponential voltage, and $B_{\text {batt }}=$ the exponential capacity. By controlling the bidirectional DC/DC converter, charging or discharging of the battery can be achieved.

The block diagram of the ESS control is depicted in Figure 6. The charging/discharging of the battery is controlled by a bidirectional converter, which is controlled by a generated switches signal obtained by the PWM generator, where a duty signal is the input of PWM. To obtain a duty signal, PI controllers are required; then, a 2-loop control scheme should be adopted [28]. In the $1^{\text {st }}$ scheme, we need the reference current for the inner current loop, which is the output of the PI controller where the input is the error signal between the measured DC-bus voltage and the reference voltage of the PI controller. In the $2^{\text {nd }}$ scheme, based on current regulation, the input is the error signal between battery current and reference current (depend on bus voltage side) of the PI controller and output is the duty cycle, which is given to the PWM generator to control the charging/discharging of the battery. For instance, the external voltage controller generates a negative current reference whenever the DC bus voltage exceeds the reference voltage. The duty cycle is then adjusted by the internal current loop. This adjusted duty cycle then forces the flow of current into the battery through the DC bus and the battery gets charged. Subsequently, due to extra energy absorption by the battery, the DC bus voltage gets reduced in reference. It is noted that SOC limits and charging/discharging rates should be considered as battery energy shortages.

\section{Modelling of proposed inverter control structure}

A VSC based on a typical voltage control system on grid voltage is shown in Figure 7. The proposed VSC has converted DC link voltages into 3-phase AC voltage, and a unity power factor is maintained. The proposed VSC inverter has been driven by a gate drive circuit and gate drive gating the control signal from the PWM generator of the $a b c$ phase; the input to the PWM will be the control signals 
http://wjst.wu.ac.th

coming from the output of the controllers. The mathematical model of VSC which is transformed into $d q$ frame is given by [29]:

$$
\left\{\begin{array}{l}
L_{f} \frac{d i_{d}}{d t}=V_{d}-V_{t d}+\omega L_{f} i_{q} \\
L_{f} \frac{d i_{q}}{d t}=V_{q}-V_{t q}+\omega L_{f} i_{d} \\
V_{d c} \frac{d V_{d c}}{d t}=V_{d c} I_{d c}-V_{t d} i_{d}
\end{array}\right.
$$

Where $V_{t d}$ and $V_{t q}$ are the point of common coupling (PCC) voltages in the $d q$ co-ordinate, $V_{d}$ and $V_{q}$ are the modulation voltages in the $d q$ co-ordinate, and $\mathrm{i}_{\mathrm{d}}$ and $\mathrm{i}_{\mathrm{q}}$ are the actual values of the current in the $d q$ co-ordinate.

The proposed VSC control system uses 2 control loops, an external control loop that controls the DC link voltage up to the desired limit, and an internal control loop that controls the id and iq grid currents that are active and reactive current components. Here, 3-phase current is converted into 2-phase currents in the $\alpha \beta$ co-ordinate system with the help of $a b c$ to $\alpha \beta$ transformation, and output will be $i_{\alpha}$ and $i_{\beta}$ now it is transformed into $d q$ co-ordinate with the help of $\alpha \beta$ to $d q$ transformation, and output will be $i_{d}$ $\& i_{q}$. The error signal between $i_{d}$ and $i_{d}{ }^{*}$ (MPPT maximum current) is inputted to the controller and, on another side, the error signal between $i q \& i_{q}{ }^{*}$ is inputted to another current controller. The $i_{q}{ }^{*}$ reference is set to 0 to maintain a unity power factor. The $V_{d}$ and $V_{q}$ voltage outputs of the current controller are converted into $V_{a b c-r e f}$, the 3 modulating signals used by the PWM generator. The control system uses a sampling time for the voltage and current controllers, as well as the PLL synchronization unit. Pulse generators of boost and VSC converters use fast sampling times to obtain a suitable resolution of PWM waves [30,31].

In brief to more robust as the closed-loop modification is suggested (PLL). The coordinate system (Figure 8) has $\alpha \beta$ coordinate system and has a voltage space vector (grid voltage). Now, the d-axes are misaligned, meaning they are not aligned along among the $V_{g}$ space vector, and as consequence the projection on the d-axis will give the $V_{d}$ and $V_{g}$, so there is a $V_{g}$ component; also, if it had been aligned along with $V_{g}$ if d-axis has been aligned along with $V_{g}$, then $V_{q}$ component would have been zero, now this $\theta$ is the angle between the $\alpha \beta$ coordinate and the $d q$ coordinate due to some reason. if $V_{q}$ is not zero then compares with the $V_{q}$, going to negative, and the PI controller will become active, and $\theta$ changes in such a direction that the input to the PI controller, which is the error, will tend to zero; then, $V_{q}$ will be zero to $V_{q} *$ If $V_{q} *$ is equal to zero, therefore, $V_{g}$ will tend to zero; that means it will align the d-axes along the voltage space vector, and the value of $\theta$ will come out because of the control action such that $V_{q}$ here will become zero. So, d-axes are aligned along the voltage space vector; this is a very robust mechanism because it is a closed loop that filters harmonics, surges, spikes, and other uncertainties. 


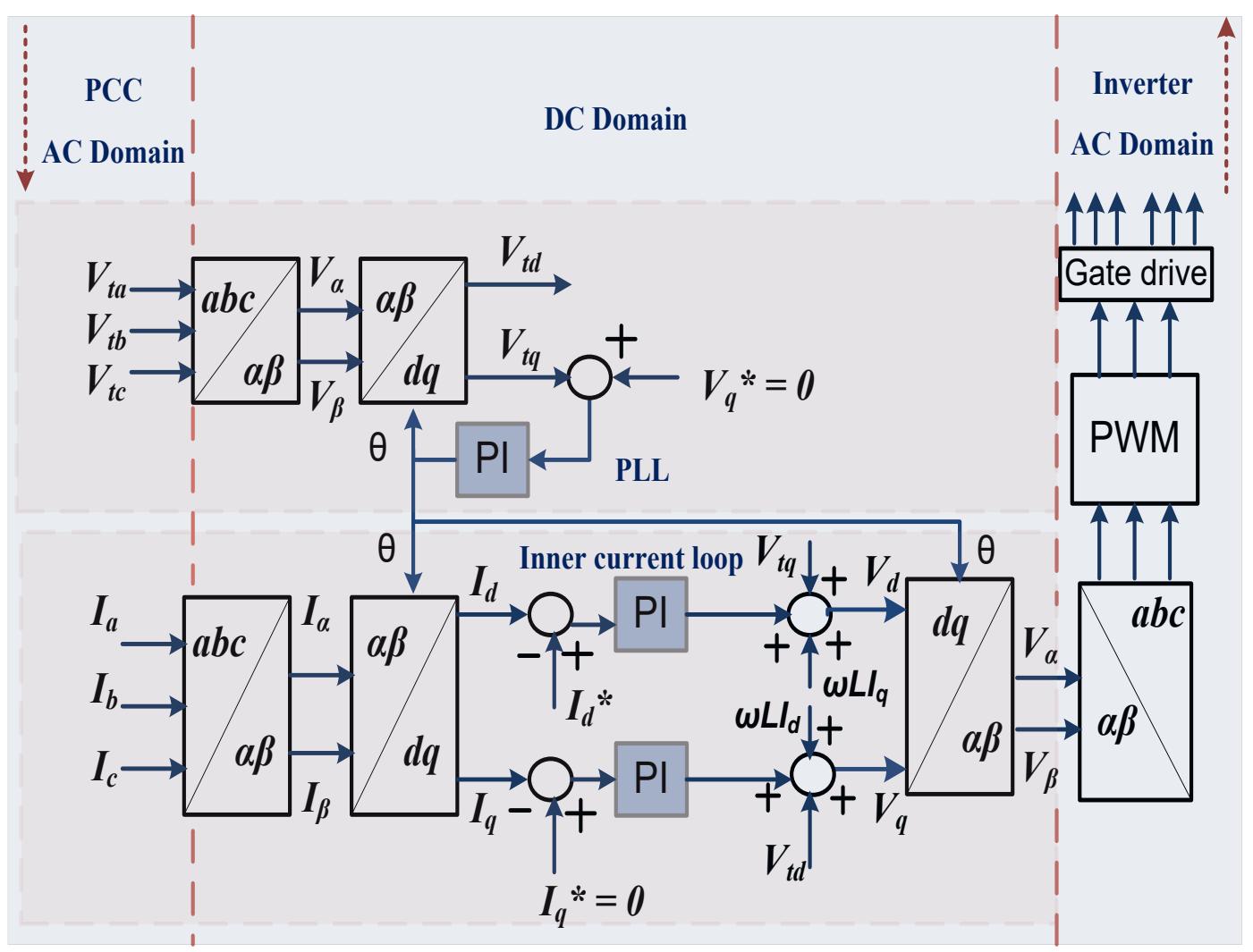

Figure 7 Proposed control strategy of VSC.

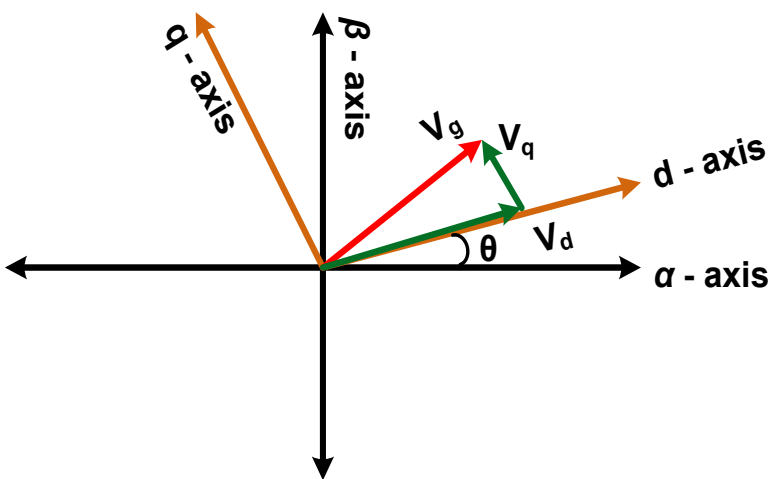

Figure 8 Phasor represantation.

\section{Simulation analysis of HPS}

The proposed hybrid power generation system and verification of the validity of the designed controller is simulated in MATLAB/Simulink. The PV/wind system with BESS is connected to the grid through the $\mathrm{DC} / \mathrm{DC}$ converter, AC/DC converter DC/DC bidirectional controller, and 3-phase inverter. Where parameters of a hybrid power generation system are listed in Table 1, a model of the proposed 
http://wjst.wu.ac.th

hybrid system is simulated for operation under different scenarios, and the results are presented and discussed in this section.

Table 1 Model parameters.

The basic PV cell parameters

\begin{tabular}{lcc}
\hline Module type: SPR-305E-WHT-D & & \\
\hline Parameter & Symbol & Specification \\
\hline Maximum output power & $\mathrm{P}_{\mathrm{p}}$ & $302.226 \mathrm{~W}$ \\
Open circuit voltage & $\mathrm{V}_{\mathrm{oc}}$ & $64.2 \mathrm{~V}$ \\
Voltage at maximum & $\mathrm{V}_{\mathrm{mp}}$ & $54.7 \mathrm{~V}$ \\
Short circuit current & $\mathrm{I}_{\mathrm{sc}}$ & $5.96 \mathrm{~A}$ \\
Current at maximum & $\mathrm{I}_{\mathrm{mp}}$ & $5.58 \mathrm{~A}$ \\
Number of cells in series & $\mathrm{N}_{\mathrm{s}}$ & 5 \\
Number of cells in parallel & $\mathrm{N}_{\mathrm{p}}$ & 66 \\
\hline
\end{tabular}

Wind system (PMSM) parameters

Module type: PM synchronous machine

\begin{tabular}{lcc}
\hline Parameter & Symbol & Specification \\
\hline Turbine rated power & $\mathrm{P}_{\mathrm{T}}$ & $20 \mathrm{~kW}$ \\
Nominal voltage & $\mathrm{V}_{\mathrm{T}}$ & $392.68 \mathrm{~V}$ \\
Nominal frequency & $\mathrm{F}$ & $50 \mathrm{~Hz}$ \\
Constant torque & $\mathrm{T}$ & 60.70 \\
Inertia & $\mathrm{J}$ & $5.5 \mathrm{e}-3 \mathrm{Kg} \cdot \mathrm{m}^{2}$ \\
Numbers of pole & $\mathrm{P}$ & 4 \\
\hline
\end{tabular}

Battery parameters

Battery type: Nickle-Metal-Hybrid

\begin{tabular}{lcc}
\hline Parameter & Symbol & Specification \\
\hline BESS nominal voltage & $\mathrm{V}_{\text {Batt }}$ & $450 \mathrm{~V}$ \\
BESS capacity & $\mathrm{B}_{\mathrm{C}}$ & $150.66 \mathrm{Ah}$ \\
State of charge & $\mathrm{SOC}$ & $60 \%$ \\
\hline
\end{tabular}

Table 2 Events during operations.

\begin{tabular}{clc}
\hline Events & Operations & Time (s) \\
\hline 1 & Solar irradiation ramps down & 1 \\
2 & Solar irradiation ramps up & 1.6 \\
3 & Temperature ram up & 2.4 \\
4 & Fault switched in & 0.42 \\
5 & Load 1 switched in & 0.58 \\
6 & Load 2 + Load 3 switched in & 1 \\
\hline
\end{tabular}




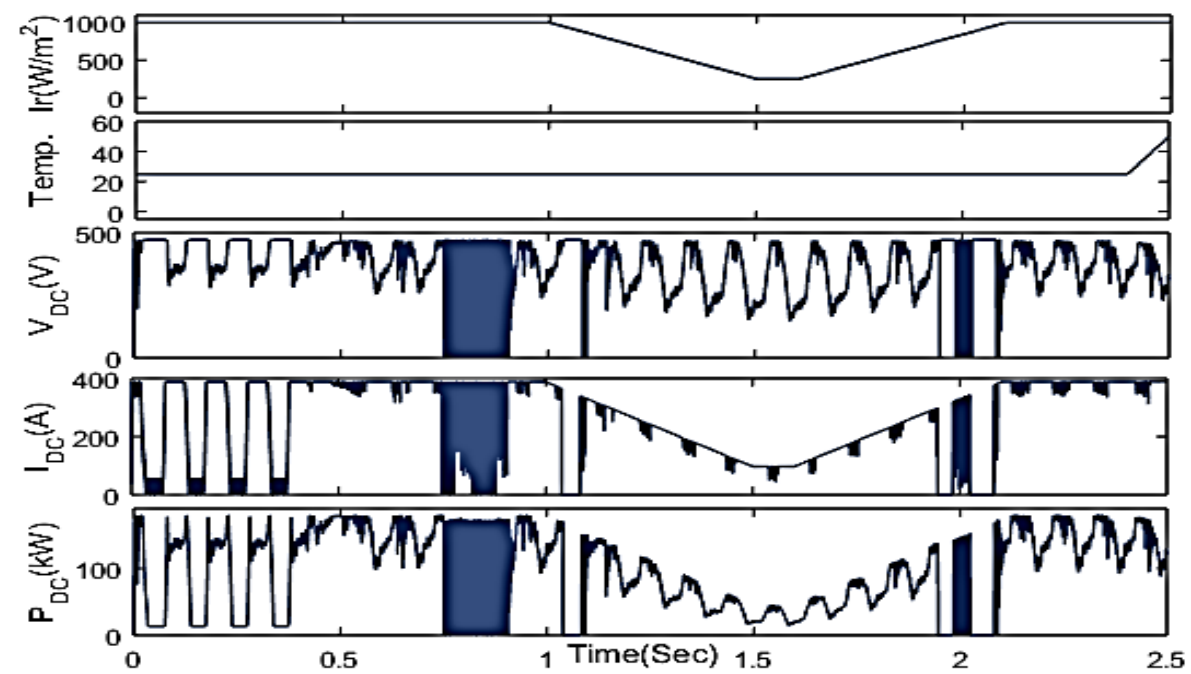

Figure $9 \mathrm{PV}$ irradiation and temperature and DC-link voltage, current, and power under the untuned controller.

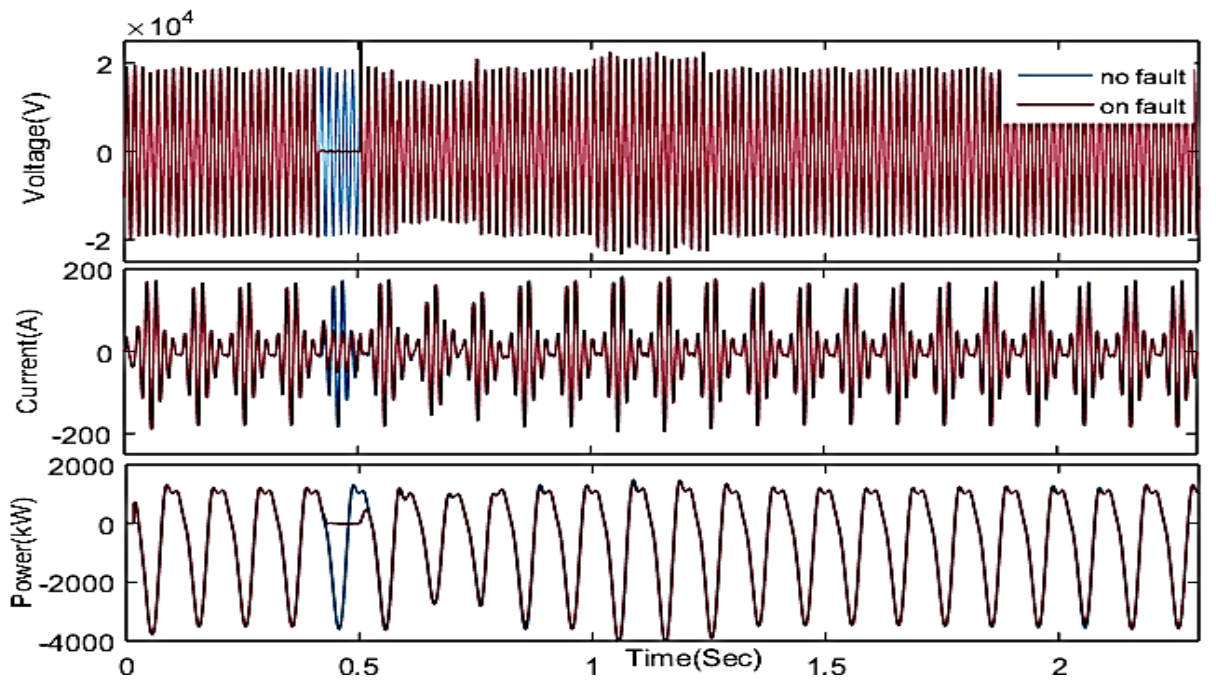

Figure 10 Inverter output voltage, current, and power under the untuned controller. 


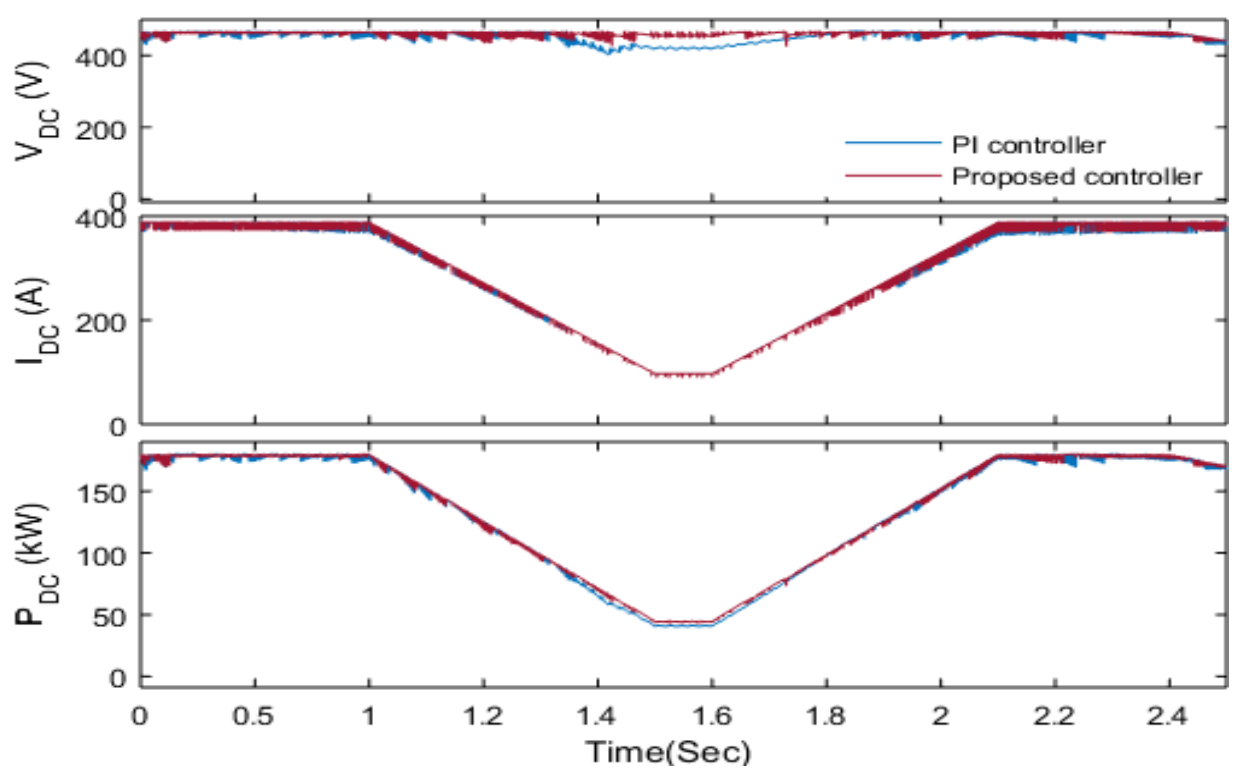

Figure 11 PV irradiation and temperature and DC-link voltage, current, and power under the proposed controller.

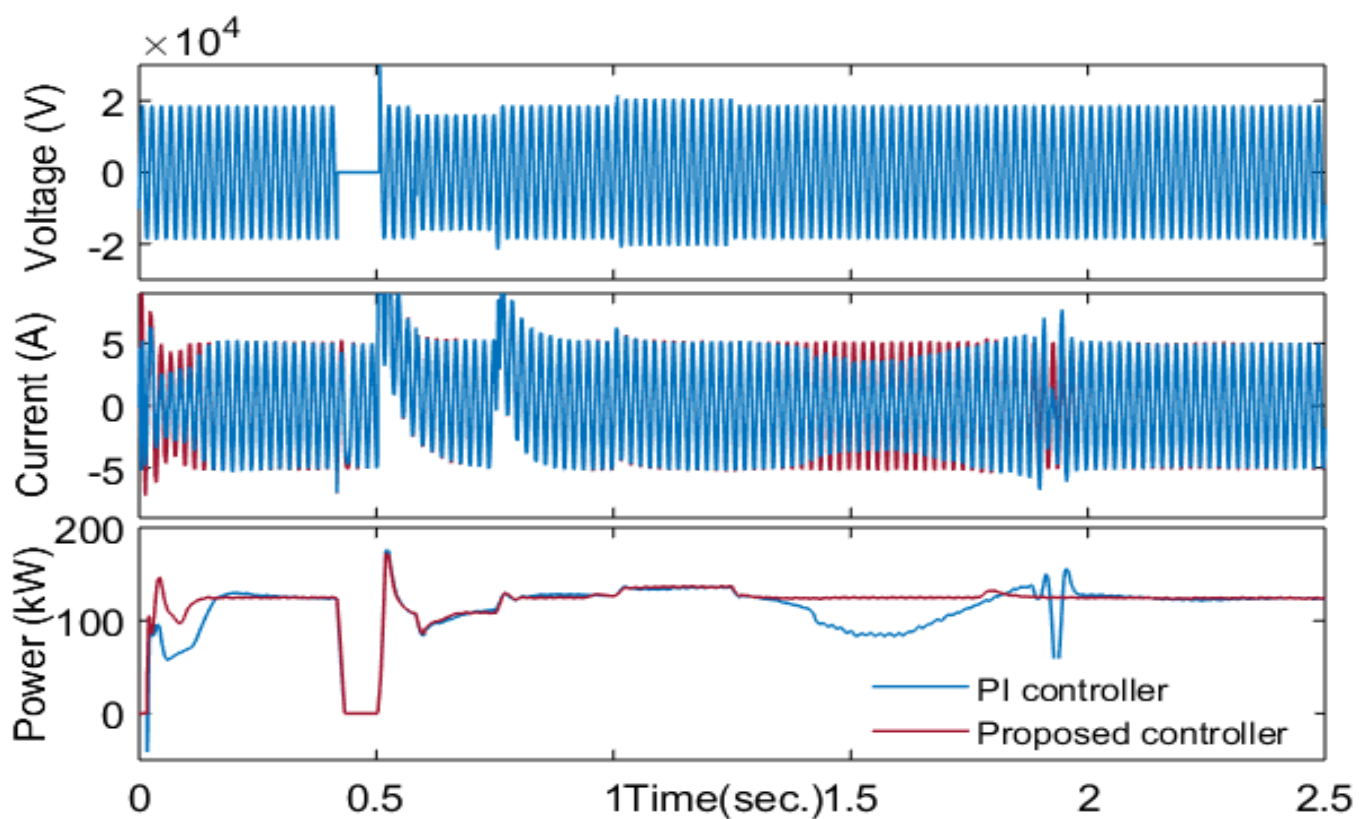

Figure 12 Inverter output voltage, current, and power under the proposed controller. 


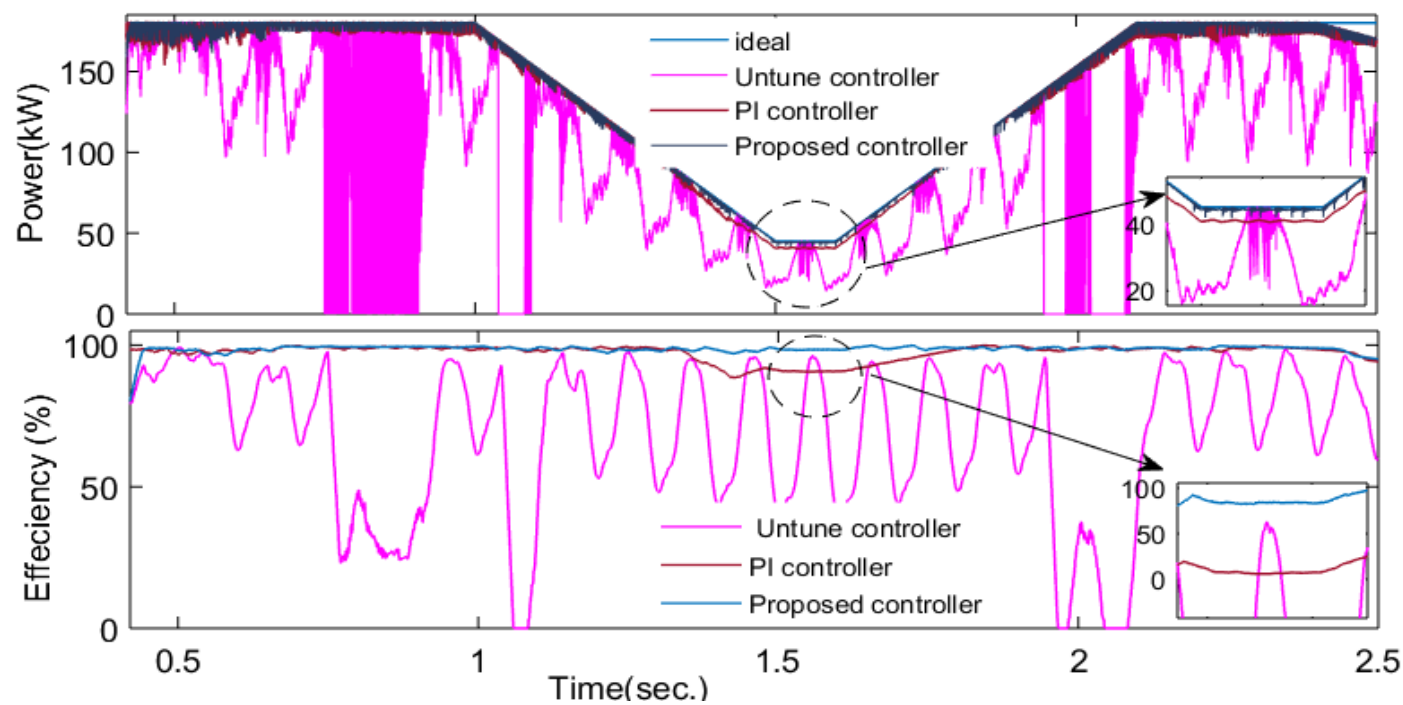

Figure 13 DC-link power and efficiency.

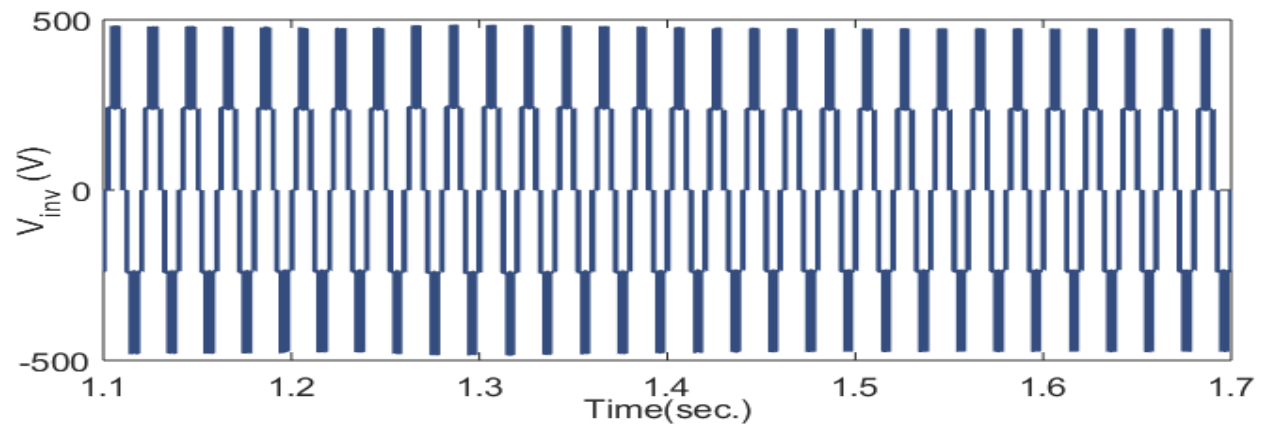

Figure 14 Inverter output voltage.

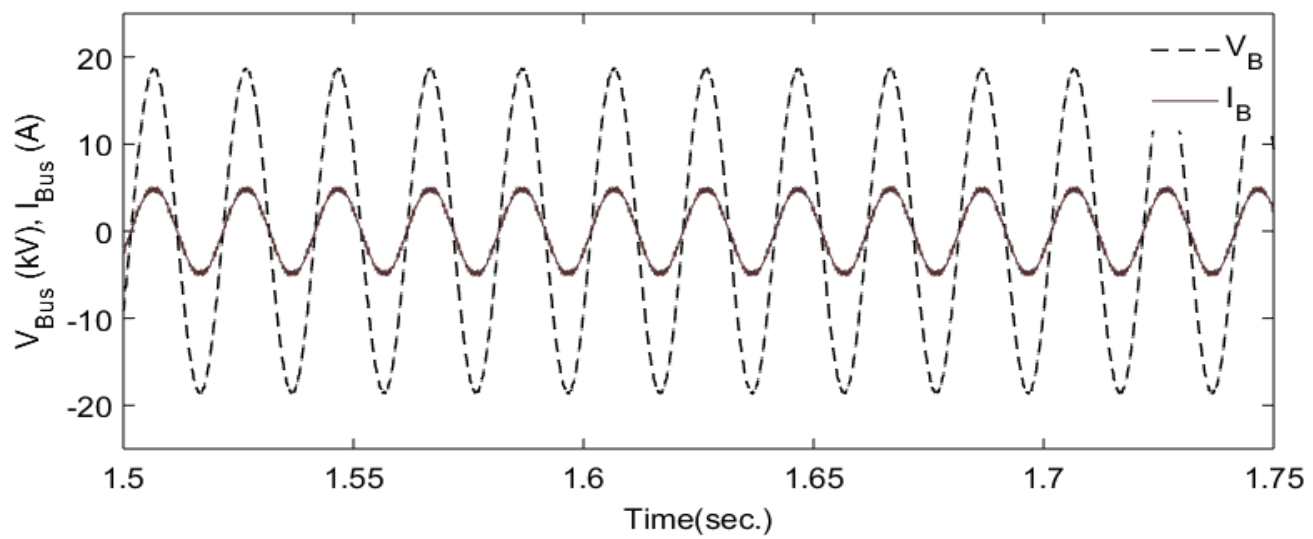

Figure 15 Bus voltage and current. 


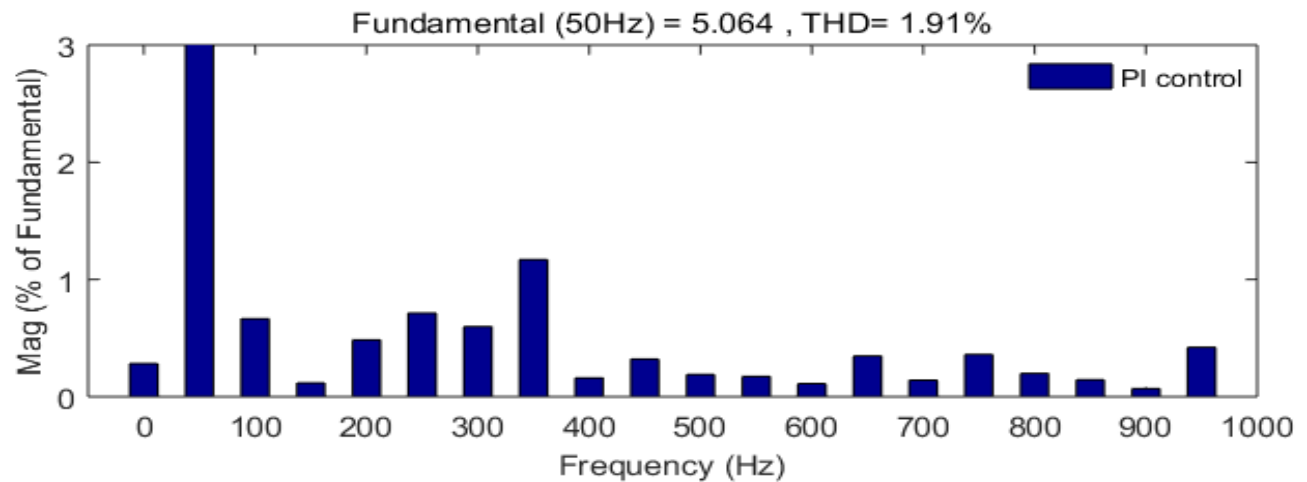

Figure 16 THD in grid current with PI controller.

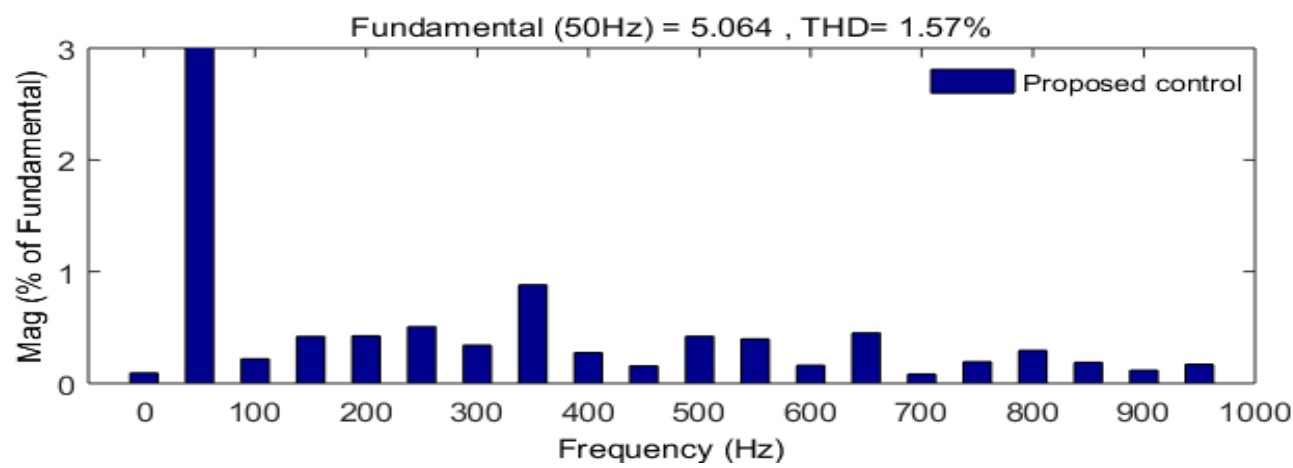

Figure 17 THD in grid current with proposed controller.

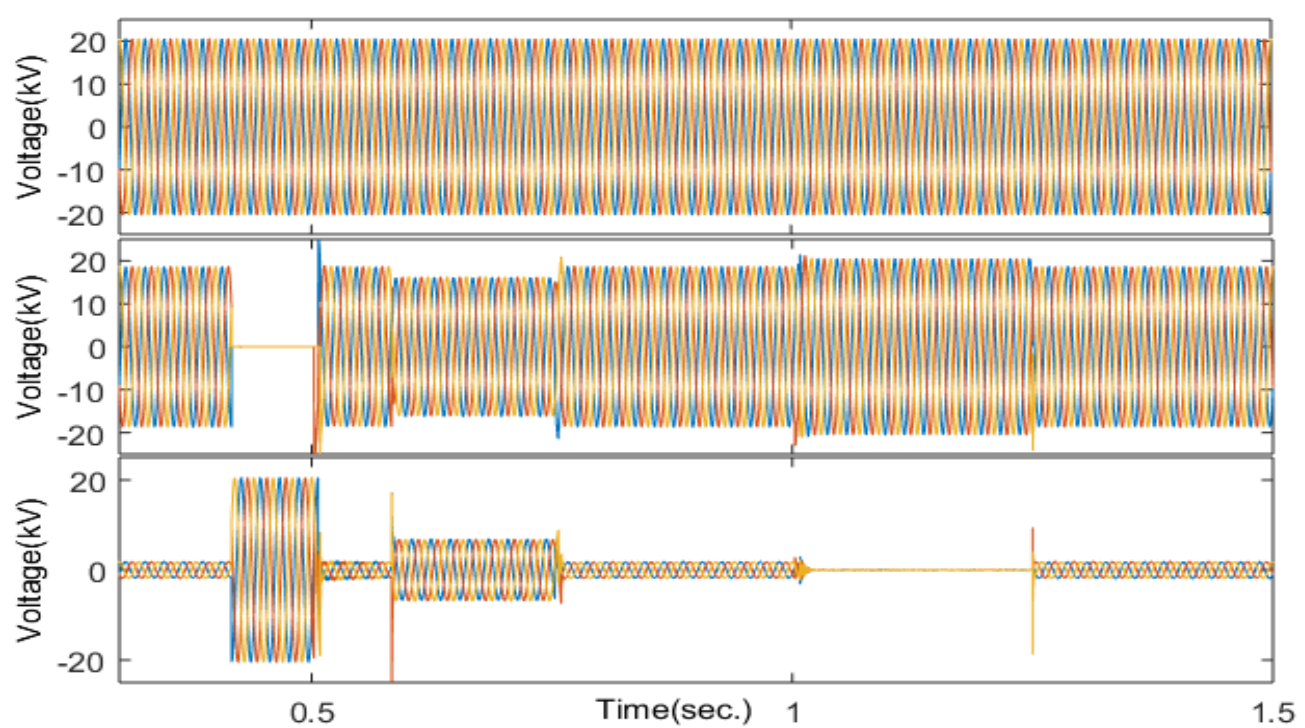

Figure 18 Performance analysis of voltage interruption, voltage sag, and voltage swell. 


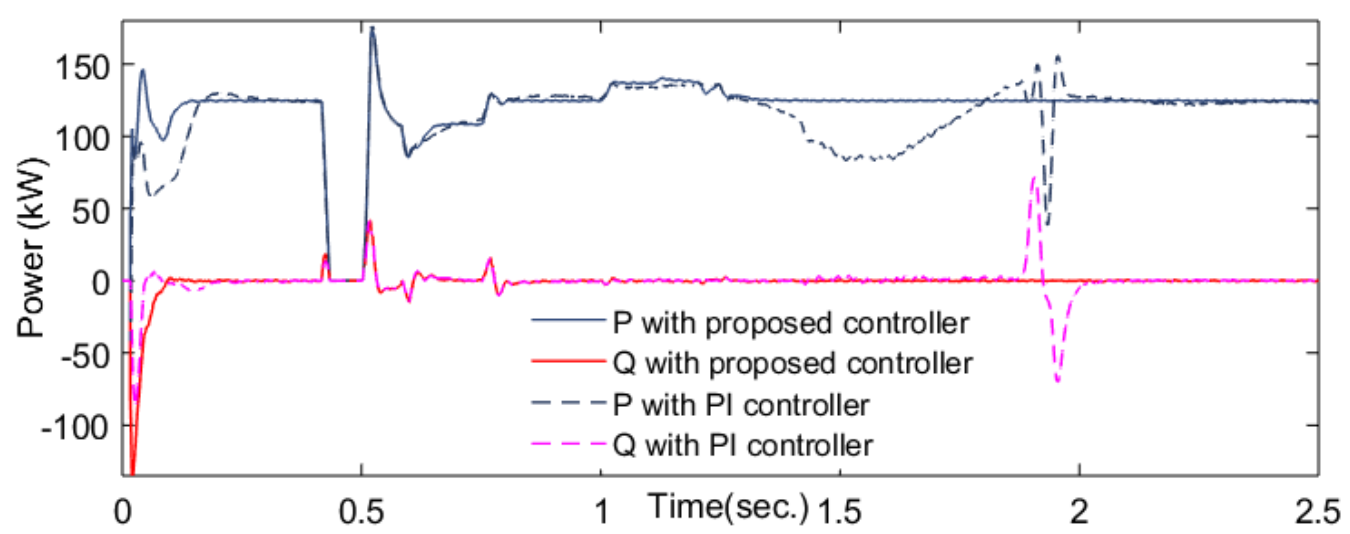

Figure 19 Active and reactive power.

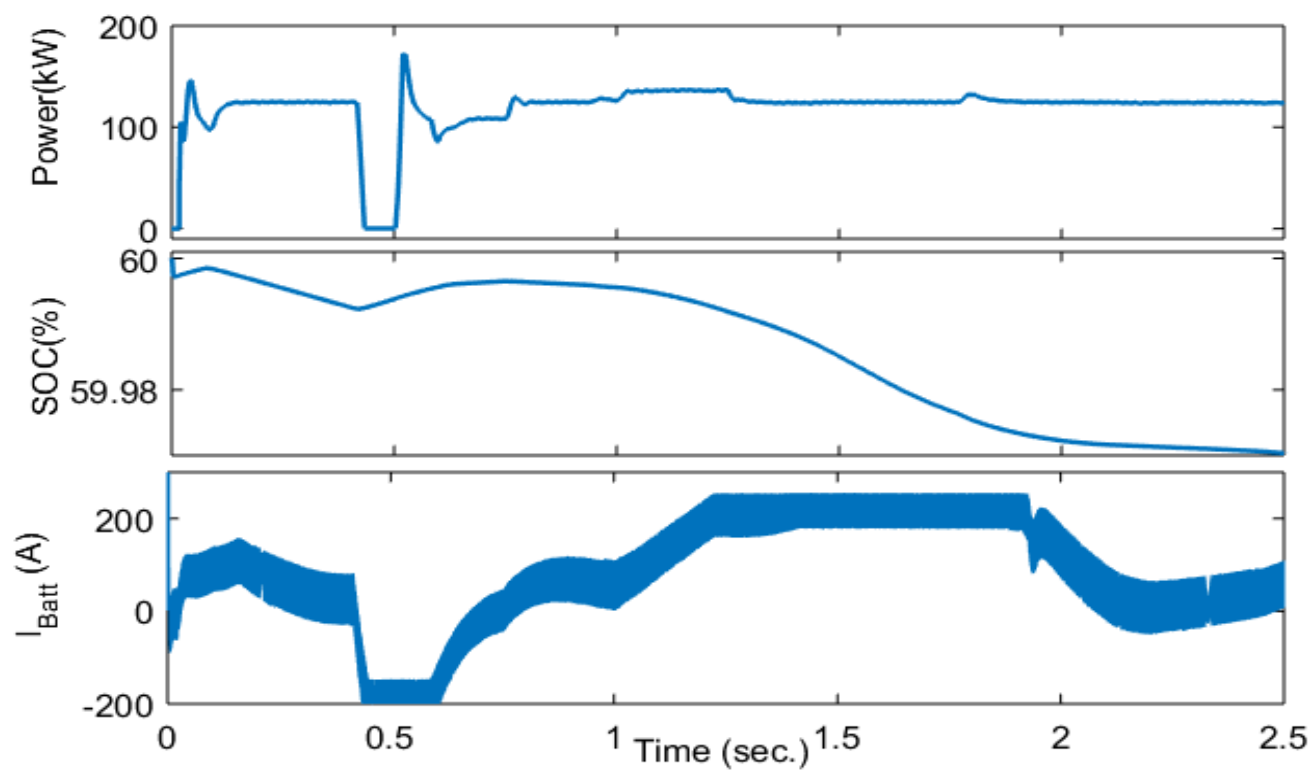

Figure 20 Performance analysis of BESS.

\section{Results and discussion}

In this paper, the controller can be tested under variations of weather, environment, and other situational conditions, in terms of Figure 9, and the operational event is shown in Table 2; it can be seen that the irradiation of the PV array was $1000 \mathrm{~W} / \mathrm{m}^{2}$ until $\mathrm{t}=1 \mathrm{~s}$. After that, the light radiation dropped to $250 \mathrm{~W} / \mathrm{m}^{2}$ up to $1.5 \mathrm{~s}$, and about to $0.1 \mathrm{~s}$ later, the irradiation gradually increased to $1000 \mathrm{~W} / \mathrm{m}^{2}$. The ambient temperatures were maintained at $25^{\circ} \mathrm{C}$ from 0 to $2.4 \mathrm{~s}$, after that, ambient temperature went up from 25 to $50{ }^{\circ} \mathrm{C}$ during the time 2.4 to $2.5 \mathrm{~s}$ in wind system, the wind speed was taken as $12 \mathrm{~m} / \mathrm{s}$ constants during all durations. The effect of electrical load variation and the faulty situation created an undesirable situation in the system. This paper presents 2 cases according to the controller. 
Case 1. In the $1^{\text {st }}$ case, the 3-level PWM generator was used as the controller, which fed the unsynchronized signal to the inverter of the hybrid power generate system; for this reason, the power fluctuation was not overcome, and the output voltage, current, and power at the DC-link side had continuous fluctuation. Figure10 shows the effect of a 3-phase fault at 0.42 to $0.5 \mathrm{~s}$ and the inductive load connected from 0.58 to $0.75 \mathrm{~s}$ and dynamic load with the resistive load connected through the system from 1 to 1.25 s. Figure 10 shows the electrical quantities at the bus (PCC) had oscillation and disturbance in voltage, current, and power. The unbalanced voltage is also represented in voltage waveform, while the 3-phase fault and loads are applied on the load bus, according to the conditional event period given in Table 2, and the effect of with and without fault were visible during 0.42 to $0.5 \mathrm{~s}$ in the waveform of power, current, and voltage. Where the effect of load 1, 2 and 3 was shown in the waveforms of power, current, and voltage at switching time 0.58 and $1 \mathrm{~s}$, the unturned controller (3-level PWM generator) gave a very poor result, which was not desirable in the HPG system.

Case 2. On the AC side, the grid injected active power and reactive power are controlled by the daxis and q-axis components of grid voltage and current. With the help of the proposed controller, the active power was set based on the actual requirement, while the reactive power was kept at 0 . The modulation index and duty ratio worked together according to grid voltage and current to produce the PWM signals and also interlinked with the DC/DC bidirectional controller of BESS for smooth power to improve the PQ of the HPG system. Figure 11 shows the voltage, current, and power waveforms at DClink under the PI controller and the proposed hybrid controller, where the voltage across both capacitors $\mathrm{C}_{1}$ and $\mathrm{C}_{2}$ can be seen to be nearly constant during the performance of the system. Where the proposed controller gave better results than the PI controller, as shown by the proposed controller-based DC link, voltage is smoother than the PI controller from 1.42 to $1.9 \mathrm{~s}$ and gets smooth output power and current at the DC side. Figure 12 shows the comparative analysis of voltage, current, and power at PCC under both PLL-based VSC controller and PI controller. Due to the effect of load variation and fault, poor PQ is obtained, so improvement in PQ is achieved by the management of battery SOC through controlling the injection of power to the grid.

Figure 13 shows the performance of the whole system under the conditional situation with both the unturned controller and proposed hybrid controller where power at dc-link is performed according to this controller and compared with ideal power. The hybrid power generates system can be also analyzed according to this controller, and it can be seen from this perspective that the efficiency of the hybrid control system is nearly $98 \%$, while the efficiency of the other unturned controller system is less than 50 $\%$ of yellow's expectation. Figure 14 shows the 3-level output voltage of the inverter has better performance than the PI controller. The single-phase bus current in phase with bus voltage and a unity power factor is maintained that feeds maximum power into the grid, presented in Figure 15.

When the system operates under various atmospheric and operating conditions, the quality of output of the HPG system will decrease, which is shown in Figures 16 and 17; the THD of the gid current injected by using the proposed controller was $1.57 \%$, while the THD injected by using the PI controller was $1.91 \%$. In the analysis of the simulation results, as shown above, the proposed controller can make better grid active power and reactive power to improve the power quality of the HPG system, and this can be seen by comparison of the proposed controller and PI controller

Figure 18 shows the performance analysis of the voltage sag, swell, and interruption. In the effect of load variation and 3-Ø fault at the load bus, the bus voltage of the HPG system suddenly decreases from the peak value of $18.5 \mathrm{kV}$ to nearly $0 \mathrm{kV}$ during 0.42 to $0.5 \mathrm{~s}$ at fault situation. While 3 different load are connected at system during 0.58 to $0.75 \mathrm{~s}$, the bus voltage decreases from 18.5 to $16 \mathrm{kV}$ and, during 1.0 to $1.25 \mathrm{~s}$, the voltage rises to $20.5 \mathrm{kV}$. To maintain grid voltage, the required voltage is compensated by the designed controller, as shown in the last graph of Figure 18.

The DC link voltage can be seen changed because of fault and load connection-disconnection; due to this reason, at the supply side, voltage interruption, sag, and swell accrued. This will affect the system performance. Therefore, the DC link voltage was maintained at a constant level, with the utilization of the proposed hybrid VSC controller and BESS. Figure 20 shows the comparative performance analysis of active power and reactive power. Here, with $3-\varnothing$ fault, load variation was introduced in the HPG system at the time duration, given as Table 2. These conditions affected the active power and reactive power at 
http://wjst.wu.ac.th

the grid and accrued the PQ problem at the grid side. Here, different types of controllers were applied for this operational condition, and the PQ enhancement were analyzed. The proposed hybrid controller maintained the active power at the actual requirement, while the reactive power was kept at 0 all the time, as shown in Figure 19, and enhanced the power quality better than the PI controller. Figure 20 shows the performance analysis of the battery energy storage system under such an operational condition. It can be seen the discharge and charge of battery maintained the power fluctuation with the help of the bidirectional current controller interlink with the hybrid controller which was controlled by generated switches signals s1 and s2. This was able to maintain the DC-bus voltage because the charging current was properly regulated to compensate for the power fluctuation. When fault accrued during 0.42 to $0.5 \mathrm{~s}$, the bus voltage suddenly decreased, after which bus voltage was reduced more than the reference voltage, which resulted in discharging the battery. While applying a three-phase load, the duty cycle forced the current flow from the DC bus to the battery for charging the battery. The performance of the battery current and SOC waveform is shown in Figure 20.

\section{Conclusions}

In this paper, a proposed robust PLL-based hybrid VSC controller was designed. Simulation results as obtained were compared with the PI controller-based converter to address issues of system parameter uncertainty, power fluctuation, and power quality. The proposed controller was able to operate the HPG system at its maximum power. Therefore, the DC link voltage was always kept in nominal value. While the intermittent problem was solved by the battery, SOC was managed through controlling the power injected into the utility grid.

\section{References}

[1] AF Tazay, AMA Ibrahim, O Noureldeen and I Hamdan. Modeling, control, and performance evaluation of grid-tied hybrid PV/wind power generation system: Case study of Gabel El-Zeit region, Egypt. IEEE Access 2020; 8, 96528-42.

[2] A Merabet, KT Ahmed, H Ibrahim, R Beguenane and AM Ghias. Energy management and control system for laboratory scale microgrid based wind-PV-battery. IEEE Trans. Sustain. Energ. 2016; 8, 145-54.

[3] G Singh, P Baredar, A Singh and D Kurup. Optimal sizing and location of PV, wind and battery storage for electrification to an island: A case study of Kavaratti, Lakshadweep. J. Energ. Storage 2017; 12, 78-86.

[4] D Hui and X Lai. Battery energy storage station (BESS)-based smoothing control of photovoltaic (PV) and wind power generation fluctuations. IEEE Trans. Sustain. Energ. 2013; 4, 464-73.

[5] SS Martin, A Chebak, AE Ouafi and M Mabrouki. Modeling and simulation of hybrid power system integrating wind, solar, biodiesel energies and storage battery. In: Proceedings of the International Renewable and Sustainable Energy Conference, Marrakech, Morocco. 2016, p. 45763.

[6] R Sebastian. Battery energy storage for increasing stability and reliability of an isolated wind diesel power system. IET Renew. Power Generat. 2016; 1, 296-303.

[7] BP Hayes, A Wilson, R Webster and SZ Djokic. Comparison of two energy storage options for optimum balancing of wind farm power outputs. IET Generat. Transm. Distrib. 2016; 10, 832-9.

[8] MP Bonkile and V Ramadesigan. Power management control strategy using physics based battery models in standalone PV-battery hybrid systems. J. Energ. Storage 2019; 23, 258-68.

[9] H Nian and Y Song. Direct power control of doubly fed induction generator under distorted grid voltage. IEEE Trans. Power Electron. 2013; 23, 894-905.

[10] L Qu and W Qiao. Constant power control of DFIG wind turbines with supercapacitor energy storage. IEEE Trans. Ind. Appl. 2010; 47, 359-67.

[11] MFM Arani and EF El-Saadany. Implementing virtual inertia in DFIG-based wind power generation. IEEE Trans. Power Syst. 2012; 28, 1373-84. 
http://wjst.wu.ac.th

[12] S Jha, I Hussain, B Singh and S Mishra. Optimal operation of PV-DG-battery based microgrid with power quality conditioner. IET Renew. Power Generat. 2018; 13, 418-26.

[13] N Mendis, KM Muttaqi and S Perera. Active power management of a super capacitor battery hybrid energy storage system for standalone operation of DFIG based wind turbines. In: Proceedings of the IEEE Industry Applications Society Annual Meeting, Las Vegas, USA. 2012, p. 1-8.

[14] A Bouharchouche, EM Berkouk and T Ghennam. Control and energy management of a grid connected hybrid energy system PV-wind with battery energy storage for residential applications. In: Proceedings of the $8^{\text {th }}$ International Conference and Exhibition on Ecological Vehicles and Renewable Energies, Monte Carlo, Monaco. 2013, p. 1-11.

[15] MB Camara, B Dakyo and H Gualous. Polynomial control method of DC/DC converters for DCbus voltage and currents management - battery and supercapacitors. IEEE Trans. Power Electron. $2011 ; 27,1455-67$.

[16] RA Badwawi, M Abusara and T Mallick. A review of hybrid solar PV and wind energy system. Smart Sci. 2015; 3, 127-38.

[17] Y Sawle, SC Gupta and AK Bohre. PV-wind hybrid system: A review with case study. Cogent Eng. $2016 ; 3,1189305$.

[18] O Noureldeen and AMA Ibrahim. Modeling, implementation and performance analysis of a gridconnected photovoltaic/wind hybrid power system. In: Proceedings of the International Conference on Innovative Trends in Computer Engineering, Aswan, Egypt. 2018, p. 296-304.

[19] O Rahman, KM Muttaqi and D Sutanto. High temperature superconducting devices and renewable energy resources in future power grids: A case study. IEEE Trans. Appl. Supercond. 2019; 29, 3800404.

[20] N Bizon. Effective mitigation of the load pulses by controlling the battery/SMES hybrid energy storage system. Appl. Energ. 2018; 229, 459-73.

[21] G Kannayeram, NB Prakash and R Muniraj. Intelligent hybrid controller for power flow management of PV/battery/FC/SC system in smart grid applications. Int. J. Hydrogen Energ. 2020; 45, 21779-95.

[22] PK Pandey and KS Sandhu. Multi diode modelling of PV cell. In: Proceedings of the IEEE $6^{\text {th }}$ India International Conference on Power Electronics, Kurukshetra, India. 2014, p. 1-4.

[23] D Sinha, AB Das, DK Dhak and PK Sadhu. Equivalent circuit configuration for solar PV cell. In: Proceedings of the $1^{\text {st }}$ International Conference on Non-Conventional Energy, Kalyani, India. 2014, p. 58-60.

[24] L Pan and X Wang. Variable pitch control on direct-driven PMSG for offshore wind turbine using repetitive-TS fuzzy PID control. Renew. Energ. 2020; 159, 221-37.

[25] DM Yehia, DA Mansour and W Yuan. Fault ride-through enhancement of PMSG wind turbines with DC microgrids using resistive-type SFCL. IEEE Trans. Appl. Supercond. 2018; 4, 5603105.

[26] KS Sandhu and A Mahesh. A new approach of sizing battery energy storage system for smoothing the power fluctuations of a PV/wind hybrid system. Int. J. Energ. Res. 2016; 40, 1221-34.

[27] J Hua, Y Shana, Y Xub and JM Guerreroc. A coordinated control of hybrid ac/dc microgrids with PV-wind-battery under variable generation and load conditions. Electr. Power Energ. Syst. 2019; 104, 583-92.

[28] T Ma, MH Cintuglu and OA Mohammed. Control of hybrid ac/dc microgrid involving energy storage and pulsed loads. IEEE Trans. Ind. Appl. 2017; 53, 567-75.

[29] S Jian. Impedance-based stability criterion for grid-connected inverters. IEEE Trans. Power Electron. 2011; 26, 3075-8.

[30] Q Jia, G Yan, Y CAI, Y Li and J Zhang. Small-signal stability analysis of photovoltaic generation connected to weak AC grid. J. Mod. Power Syst. Clean Energ. 2019; 7, 254-67.

[31] AS Chatterjee. A bus clamping PWM-based improved control of grid tied PV inverter with LCL filter under varying grid frequency condition. IETE J. Res. 2021. https://doi.org/10.1080/03772063.2020.1844067 